УДК 378.147:347.96(477)

DOI:

Зоряна Височан, аспірант ДВНЗ “Прикарпатський наџіональний університет імені Василя Стефраника”

\title{
КОМПЕТЕНТНІСНИЙ ПІДХІД ФОРМУВАННЯ КУЛЬТУРИ УКРАЇНСЬКОГО ДІАЛОГІЧНОГО МОВЛЕННЯ МАЙБУТНІХ ПРАВОЗНАВЦІВ
}

Проаналізовано сучасні педагогічні проблеми фахової підготовки майбутніх юристів у проиесі формування професійної комунікаџї; проаналізовано процес інтеграџї як умови якісної підготовки майбутніх фахівців; місие професійної комунікації у системі фахової підготовки майбутніх юристів. На основі наукових джерел окреслено педагогічні умови формування комунікативної компетентності студентів-правників. Акиентується на формуванні діалогічного мовлення у професійній комунікаиї під час занять. У статті окреслено також окремі аспекти розгляду прочесу формування культури професійно-правового спілкування як педагогічної проблеми.

Ключові слова: діалог; спілкування; діалогічне навчання; майбутній юрист; комунікативна компетентність; професійна комунікачія; професійно-правове спілкування.

Jim. 5.

Zoryana Vysochan, Postgraduate Student Precarpathian Vasyl Stefanyk National University

\section{COMPETENCY-BASED APPROACH FOR THE FORMATION OF CULTURE OF UKRAINIAN DIALOGUE SPEECH OF FUTURE LAWYERS}

Modern pedagogical problems of professional training of future lawyers in the process of professional communication formation are analyzed; the process of integration as a condition for quality training of future specialists is analyzed; the place of professional communication in the system of professional training of future lawyers is considered. On the basis of scientific sources, pedagogical conditions for the communicative competence formation among law students are outlined. The emphasis is on the formation of dialogue speech in professional communication during classes. The article also outlines some aspects of the process of formation of culture of professional legal communication as a pedagogical problem.

The article outlines the pedagogical conditions of the lawyers' communicative competence on the basis of scientific sources and teaching experience at the judicial faculty. An attention is paid in particular to the formation of motivational-value ratio of students to professional communication at the lessons of the course "Ukrainian language for professional purposes". Also the article enriches the contents of special disciplines with innovative technologies that stimulate students to speech activity.

It was indicated that the lawyer's professional competence consisted of the following components: 1) a motivational target component; 2) a cognitive component; 3) a social component; 4) axiological component; 5) auto-psychological component.

The article presents some aspects of treating the process of forming the culture of professional and legal communication as a pedagogical problem. An attention is paid to the analysis of definitive system, the structure of professional and legal communication, the classification of its types.

Keywords: a dialogue; communication; dialogical learning; the lawyers'; communicative competence; professional communication; professional and legal communication.

П остановка проблеми. Сьогодні в педагогічній науці й професійній освіт усталилася думка, відповідно до якої сучасний фахівець повинен бути не лише кваліфікованим, а й передусім компетентним. Це передбачає не лише володіння певними знаннями, уміннями й навичками, необхідними для ефективної професійної діяльності, а й творчу реалізацію їх, формування ініціативності, самостійності в ухваленні рішень, здатність до саморозвитку і самовдосконалення. Відтак професійна компетентність допомагає фахівцеві не тільки якісно розв'язувати різноманітні завдання, а й творчо підходити до розв'язання складних завдань за умов стандартних i нестандартних ситуацій. Ідеться про компетентнісний підхід до процесу формування майбутнього фахівця. Тому за умов компетентнісного підходу до навчання у вищій школі діалогізація навчального процесу найбільш актуальна, позаяк вона якнайкраще відображає природу дидактичної взаємодії, співпраці студента та викладача, слугує створенню оптимальних умов для діалогічного спілкування в системі стосунків "викладач - студент". Саме діалогічне навчання розглядаємо як умову реалізації компетентнісного підходу до формування мовленнєвої культури майбутніх правознавців 


\section{КОМПЕТЕНТНІСНИЙ ПІДХІД ФОРМУВАННЯ КУЛЬТУРИ УКРАЇНСЬКОГО ДІАЛОГІЧНОГО МОВЛЕННЯ МАЙБУТНІХ ПРАВОЗНАВЦІВ}

зокрема та професійної комунікації у системі фахової підготовки майбутніх юристів загалом.

Мета статті - схарактеризувати теоретичні засади формування культури українського діалогічного мовлення майбутніх правознавців крізь призму компетентнісного підходу.

Аналіз останніх досліджень і публікацій. Проблема, порушена в назві статті, $\epsilon$ багатогранною, іiі окремі аспекти досліджували українські та зарубіжні вчені: А. Білоножко, М. Ковальов, М. Криськів, В. Савіщенко, О. Уваркіна та ін. (комунікативна культура як складник професійної компетентності юриста); Н. Бібік, П. Біленчук, Н. Волкова, Н. Свдокимова, І. Срмаков, І. Зимня, Н. Кічук, С. Клепко, О. Овчарук, Л. Петровська, Дж. Равен, В. Стрельніков, А. Хуторськой та ін. (основи компетентнісної освіти); І. Бенедик, П. Біленчук, А. Жалінський, О. Скакун, С. Сливка та ін. (культурологічні, морально-етичні, психологічні, порівняльно-правові, історичні аспекти фахової підготовки майбутніх юристів).

Виклад основного матеріалу. Мовленнєва обізнаність (компетентність) як складник і важлива передумова комунікативної компетентності майбутніх юристів грунтується на системних знаннях з рідної мови і мовлення, засвоєних у школі, відповідних уміннях і навичках, загальнокультурному розвиткові студентів тощо. Звісно, постулат права залишається стрижнем юридичної діяльності та визначає ії специфіку зпоміж інших професій на ринку праці. Це зумовлено їі суспільною місією, що впливає на зміст базових компетентностей майбутніх юристів, особливо комунікативної, яка забезпечує ефективність ділових контактів, діалогування в соціальному середовищі [5]. Обсяг, якість та інші показники змісту вищої юридичної освіти відображає державний стандарт, який визначає характер і змістову наповненість навчальних планів (базових й окремих 3ВО), навчальних програм з дисциплін та навчально-методичного забезпечення (підручники, посібники тощо). У своїй сукупності вони окреслюють і забезпечують формування професійної компетентності юриста.

Спираючись на результати дослідження вчених $[2 ; 3 ; 4]$, при організації експериментального навчання студентів, спрямованого на формування культури українського діалогічного мовлення (КУДМ), насамперед доцільно обрати такі науково-методичні підходи: системний (універсальний підхід і метод пізнання, що протистоїть стихійності, суб'єктивізму, створює умови для послідовного процесу навчання, орієнтує на інформаційну підготовку студентів, дозволяє виокремлювати й органічно поєднувати різні структурні елементи управління навчальним процесом, зокрема форми, методи, засоби нових інформаційних технологій, готовність викладачів і студентів до цілеспрямованого розвитку КУДМ); інтегративний (наближає інтегративне навчання до розвивального, включаючи основні види навчання; орієнтує на посилення у навчальному процесі засад гуманізації, теоретизації, інформатизації; надає його змісту теоретикодослідницького характеру); компетентнісний основний, оскільки спрямовує цілі навчання на здобуття результатів як сукупності компетенцій, що впливають на рівні професійних завдань; орієнтує на поєднання професійної освіти із потребами суспільства і ринку праці; вимагає застосування методик навчання, які забезпечують студента не лише знаннями, вміннями, навичками, а й досвідом професійної діяльності, прищеплюють йому впевненість у власних силах, готовність брати відповідальність за свої дії і рішення, що особливо важливо для майбутнього юриста); особистісно орієнтований - спрямовує на розвиток студента як індивідуальності й активного суб' єкта навчальної діяльності, що здійснюється на засадах гуманізму, демократизму, діалоговості, співтворчості; стимулює використання активних методів роботи; культивує унікальний досвід кожного суб'єкта і визнання цінності кожного особистісного досвіду, зокрема цінності “ситуації діалогування”; спонукає учасників навчального процесу до довірливого стилю спілкування, акцентує на важливості організації інтенсивної самостійної творчої діяльності студентів, спонукає їх до розв'язання конкретних пізнавальних й професійно важливих проблем; комунікативний, як i компетентнісний, теж $€$ засадничим для експериментальної методики мовленнєвої підготовки до діалогової комунікації у 3ВО, де готують юристів.

Адаптуючи до змісту і завдань нашої програми формування культури українського діалогічного мовлення майбутніх правознавців доробок учених 3 проблем навчання діалогічного мовлення учнів і студентів [1 та ін.], визначаємо принципи формування КУДМ майбутніх юристів:

1. Комунікативно-мовленнєвої спрямованості навчання (включає вимоги з добору лінгвістично доцільного мовного матеріалу, що забезпечує відповідний рівень професійної комунікативнодіалогічної достатності; комунікативність мовленнєвих операцій при роботі з мовним матеріалом тощо).

2. Моделювання типових комунікативних ситуацій (організація навчання українського 


\section{КОМПЕТЕНТНІСНИЙ ПІДХІДФОРМУВАННЯ КУЛЬТУРИ УКРАЇНСЬКОГО ДІАЛОГІЧНОГО МОВЛЕННЯ МАЙБУТНІХ ПРАВОЗНАВЦІВ}

діалогічного мовлення (УДМ) як серії професійнотипових комунікативних ситуацій; дотримання вимог щодо створення ситуацій для діалогічного мовлення тощо).

3. Навчання УДМ як мовної комунікативної діяльності (оволодіння діалогічною мовою як живою активною діяльністю, орієнтованою на особистість співрозмовника; орієнтує на використання інформаційно насиченого, цікавого, потенційно комунікативного екстралінвістичного матеріалу).

4. Навчання УДМ як форми соціальної поведінки (оволодіння студентами нормами поведінки, прийнятними в певних мовних соціальних і професійних середовищах; знання і вміння використовувати невербальні способи комунікації, народні мовні традиції, правила етикету міжособистісного спілкування).

5. Мовно-ситуативної стереотипності діалогічного контакту (багаторазове розігрування в процесі навчання УДМ однотипних ситуацій, що передбачають використання клішованого мовного матеріалу, який, з одного боку, полегшує, форматує процес комунікації, з іншого, спрямовує його учасників на засвоєння нових висловлювань, що не мають аналогів).

6. Типології діалогічної мови (використання різних типових видів діалогу і прийомів роботи 3 опорними матеріалами, створення типових навчальних ситуацій з формування знань, умінь, навичок УДМ).

7. Поступального підходу до навчання УДМ (послідовне формування здатності до створення окремого вислову в діалогічній зв'язці: спочатку на рівні слова, потім словосполучення, відтак повного речення та зв'язки речень, що стимулюють подальше діалогування).

8. Розподілу ролей (регулювання взаємодії окремих ролей, зокрема комунікативних, на рівнях говоріння слухання, соціальної комунікації: юрист - клієнт, колега - колега, керівник - підлеглий і т. ін.; передбачає чіткий розподіл рольових функцій у процесі навчання УДМ, щоб студенти налаштовувалися на відповідну імпровізацію й досягнення висунених завдань).

9. Взаємозв'язку вербальних і невербальних засобів спілкування, що забезпечує підвищення ефективності, результативності всього процесу діалогування.

Суть вимог як компонента програми формування КУДМ майбутніх правознавців зумовлюється iï завданнями, принципами, предметом. До таких основних вимог відносимо: a) актуальність навчального матеріалу: діалог має включати питання, які становлять безпосередній інтерес для майбутньої професійної діяльності; б) особистісна значущість, тобто усвідомлення практичної значущості КУДМ, причому не лише юридичної, а й інших сфер життєдіяльності, пов'язаних із соціальними комунікаціями; в) емоційна виразність і впливовість - діалогічна комунікація повинна впливати на чуттєво-емоційну сферу особистості студента, стимулювати, мотивувати його прагнення і бажання щодо оволодіння знаннями і навичками, які стосуються КУДМ; г) нелінійність, проблемність змісту навчального матеріалу, який повинен спонукати до дискусії, колективного чи самостійного пошуку істини; г) застосування рольових ситуацій, що сприяє утвердженню суб' єкт-суб' єктних відносин на рівні студент-викладач, дозволяє “децентрувати” їхню особистісну позицію, формує здатність розуміти інтереси "іншого", бачити ситуацію очима “іншого”; д) спільне обговорення питань, які стосуються навчального матеріалу та подій, ситуацій, що виникають в суспільстві загалом й у студентській групі зокрема.

Означені вимоги формують громадянську й особистісну позицію, здатність виважено, критично оцінювати вчинки, поведінку свою й інших. Вони безпосередньо стосуються навчання діалогічного мовлення в усній чи у письмовій формах, позаяк властива їм варіативності уможливлює самовираження студентів і таким чином дозволяє їм відпрацьовувати, запам'ятовувати окремі мовні зразки й цілі структури, які використовуються у різних комунікативних ситуаціях.

3'ясування педагогічних умов як складника експериментальної програми формування КУДМ студентів-правознавців потребують більш докладного розгляду, бо вони є важливим компонентом навчального процесу у ЗВО, що забезпечує різногалузеву професійну підготовку кваліфікованих фахівців. Категорія "педагогічні умови" - одна з базових у сучасній педагогіці, тож вона стала предметом усебічного науковотеоретичного осмислення. Існують пізні підходи й тлумачення цього феномену. 3 позицій предмета i завдань нашого дослідження трактуємо педагогічні умови як сукупність чинників, що визначають організацію навчально-виховного процесу у ЗВО та детермінують і забезпечують можливість досягнення прогнозованих результатів навчання, виховання і розвитку особистості студента. Спираємося на поширений в українській педагогіці поділ педагогічних умов на два основні рівні: перший - окреслює особистісні характеристики студентів, що зумовлюють орієнтованість навчально-виховного процесу; 
другий - позначає безпосередні обставини “класичні умови” його реалізації: зміст навчальної діяльності студентів, характер міжособистісних відносин (суб'єкт-суб'єктні стосунки між студентом і викладачем - основа освітнього простору 3ВО); взаємодія ЗВО із навколишнім середовищем й орієнтація освітнього процесу на соціально-професійні замовлення й суспільні вимоги. Означені підходи покладені в основу визначення педагогічних умов формування КУДМ майбутніх правознавців.

У такому контексті педагогічні умови також розглядаємо як необхідні й достатні обставини, від яких залежить ефективність навчального процесу, зокрема оволодіння студентами знаннями, розвиток їхньої пізнавальної самостійності та результат цілеспрямованого добору, конструювання й застосування елементів змісту, методів, організаційних форм навчання для досягнення мети формування КУДМ. Отже, педагогічними умовами реалізації експериментального навчання з формування КУДМ $\epsilon$ : а) комунікативномовленнєва спрямованість навчання УдМ; б) тематичний комплексний підхід до навчання діалогічного мовлення; в) цілеспрямована мотивація комунікативно-мовленнєвої діяльності; г) розвиток освітніх потреб і реалізація принципів, методів, що відповідають концепту розвивального навчання; г) достатній інформаційно-методичний супровід усіх етапів навчального процесу; д) системність і об'єктивність оцінювання знань, умінь, навичок студентів.

Означені педагогічні умови конкретизують чинники впливу на підвищення ефективності реалізації методики формування КУДМ студентівюристів: наявність у них певного рівня знань, умінь, навичок з УДМ; створення навчальнометодичного забезпечення технологічної програми; орієнтація викладача на використання інтерактивних методик 3 навчання УДМ; стимулювання мотивації та усвідомлення потреби в оволодінні техніками діалогової комунікації студентами тощо.

Висновок. Отже, застосування компетентісного підходу до юридичної освіти дозволяє 3'ясувати їі змістову наповненість, результативність через сукупність різновидових компетенцій, які забезпечують необхідний рівень професіоналізму випускників закладів вищої освіти цього профілю. Удосконалення мовленнєвої діяльності майбутніх правознавців зумовлюється насамперед зростаючими соціальними потребами в особистості високої мовленнєвої культури, здатної вільно користуватися всіма мовними засобами в різноманітних комунікативних ситуаціях. Саме така система слугує підвищенню рівня розвитку українського діалогічного мовлення, виробляє мовленнєву культуру майбутніх юристів. Компетентнісний підхід спрямовує цілі навчання на здобуття результатів як сукупності компетенцій, що впливають на рівні професійних завдань; орієнтує на поєднання професійної освіти iз потребами суспільства і ринку праці; вимагає застосування методик навчання, які забезпечують студента не лише знаннями, вміннями, навичками, а й досвідом професійної діяльності, прищеплюють йому впевненість у власних силах, готовність брати відповідальність за свої дії і рішення, що особливо важливо для майбутнього юриста, тощо.

Перспективи подальших досліджень. Предметом нашого подальшого дослідження $є$ зміст методики формування КУДМ, який доцільно розглядати у двох взаємопов'язаних напрямах. Перший - теоретичний - передбачає відновлення і поглиблення знань студентів 3 питань розвитку мовної культури, змісту і структури побудови діалогу, невербальних засобів спілкування, мовного професійного етикету тощо. Другий практичний - забезпечує вироблення на основі цих знань відповідних умінь, навичок, особистісних якостей, що підвищують загальний мовленнєвокомунікативний та діалогічно-мовленнєвий рівні студентів-юристів.

\section{ЛІТЕРАТУРА}

1. Бабанский Ю. К. Методы обучения в современной общеобразовательной школе: науч. изд. / Ю. К. Бабанский. - М.: Просвещение, 1985. $-208 \mathrm{c}$.

2. Кремень В. Г. Синергетика в освіті: контекст людиноцентризму: монографія / В.Г. Кремень, В.В. Ільїн. - К.: Педагогічна думка, 2012. - 368 с.

3. Сисоєва С.О. Проблеми неперервної професійної освіти: тезаурус наукового дослідження: наук. видання / С. О. Сисоєва, І. В. Соколова. К.: Вид. Дім “ЕКМО”, 2010. - 362 с.

4. Скалкин В. Л. Обучение диалогической речи / В. Л. Скалкин. - К.: Радянська школа, 1989. $158 \mathrm{c}$.

5. Яворська Г. Базові компетентності майбутніх правознавців / Г. Х. Яворська // Наукові записки Міжнародного гуманітарного університету: [збірник]. - Одеса: Фенікс, 2016. - Вип. 25. C. $220-226$.

\section{REFERENCES}

1. Babanskyi, Yu. K. (1985). Metody obucheniya v sovremennoy obshcheobrazovatelnoy shkole: nauch. izd. [Methods of teaching in a modern 


\section{ДІАГНОСТИКАСТАНУ СФОРМОВАНОСТІ КОРПОРАТИВНОӤ КУЛЬТУРИ СТУДЕНТІВ УНІВЕРСИТЕТУ}

comprehensive school]. Moscow: Education, p. 208. [in Russian].

2. Kremen, V. H. (2012). Synerhetyka v osviti: kontekst liudynotsentryzmu: monohrafiia [Synergetics in education: the context of humancenteredness]. Kyiv: Pedagogical Thought, p. 368. [in Ukrainian].

3. Sysoieva, S. O. \& Sokolova, I. V. (2010). Problemy neperervnoi profesiinoi osvity: tezaurus naukovoho doslidzhennia [Problems of Continuing
Professional Education: Thesaurus of Scientific Research]. Kyiv: Vyd. Dim “EKMO”, p. 362. [in Ukrainian].

4. Skalkyn, V. L. (1989). Obuchenye dyalohycheskoi rechy [Teaching Dialogue Speech]. Kyiv: Soviet school, p. 158. [in Russian].

5. Yavorska, H. (2016). Bazovi kompetentnosti maybutnikh pravoznavtsiv [Basic competences of future lawyers]. Scientific notes of the International Humanitarian University. Odesa: Phoenix, vol. 25, pp. 220-226. [in Ukrainian].

Стаття надійшла до редакції 26.12.2018

УДК $378.4-057.875: 316.73$

DOI:

Катерина Бровко, аспірант Київського університету імені Бориса Грінченка

\section{ДІАГНОСТИКА СТАНУ СФОРМОВАНОСТІ КОРПОРАТИВНОЇ КУЛЬТУРИ СТУДЕНТІВ УНІВЕРСИТЕТУ}

У статті висвітлюються питання діагностики стану сформованості корпоративної культури студентів університету. Наведено особливості діагностики стану сформованості корпоративної культури студентів університету. Розкрито сутність поняття “корпоративна культура особистості”. Окреслено компонентну структуру корпоративної культури особистості. Визначено критерії, показники та рівні сформованості корпоративної культури студентів університету. Описано результати проведення діагностики.

Ключові слова: діагностика; корпоративна культура; університет; студенти.

Puc. 4. Jim. 5.

Kateryna Brovko, Postgraduate Student, Kyiv Borys Hrinchenko University

\section{DIAGNOSTICS OF STATE OF FORMATION OF CORPORATE CULTURE OF UNIVERSITY STUDENTS}

The study deals with the question of the diagnosis of the formation of the corporate culture of university students. Diagnosis allows investigating the level of knowledge of students about the nature and content of the individual aspects of corporate culture and determining the attitude of students to the corporate culture of the university. Specifics of the diagnosis of the formation of the corporate culture of university students are outlined. The essence of the concepts "corporate culture of personality" is determined. The component structure of the corporate culture of the personality is outlined. Among the structural components of the corporate culture of personality are used: worldview, corporate values, style of behavior, the rules that the members of the organization adhere to. Criteria, indicators and levels of formation of the corporate culture of university students are defined. Among the indicators are singled out: understanding of the essence of corporate culture, the mechanisms of its manifestation; possession for knowledge about the corporate culture of personality; understanding of the role of corporate culture and awareness of the need to identify it in student life; knowledges of formal and informal rules and norms of activity, patterns of behavior, traditions, rituals, corporate identity, logo, flag, corporate color, branded clothes, missions, visions accepted at the university and awareness of the appropriateness of their observance; adherence to the ethics of corporate behavior, value attitude to cultural norms, rules, models of behavior, accepted in the educational environment of the university. The results of diagnostics of the formation of the corporate culture of university students are described.

Keywords: diagnostic; corporate culture; the university; students.

П останвка проблеми. На сучасному етапі розвитку країни, вища школа повинна забезпечити підготовку висококваліфікованих, конкурентоспроможних фахівців, що володіють високою сформованістю моральних уявлень, цінностей, ідеологічних настанов, норм та правил поведінки, світогляду, інтелекту, культури, а також здатні забезпечувати сталий розвиток цивілізації, самостійно і творчо мислити, швидко знаходити ефективні та нестандартні шляхи вирішення проблем. Одним iз найважливіших елементів, що забезпечує якість 